\title{
OCHRONA SYGNALISTÓW (WHISTLEBLOWERS) W KONTEKŚCIE WOLNOŚCI WYPOWIEDZI
}

\section{WPROWADZENIE}

Opinia publiczna niejednokrotnie dowiaduje się o przypadkach nadużycia czy złamania prawa dzięki osobom, które mając o tym informacje, ujawniaja je dla dobra ogółu. Tego rodzaju działanie doprowadziło do wykrycia nadużyć związanych z pozyskiwaniem danych przez amerykańskie organy śledcze (ujawnione przez Edwarda Snowdena) czy unikaniem opodatkowania w rajach podatkowych (tzw. sprawa Panama Papers). Osoby, które upubliczniły informacje o tych nadużyciach, spotkały się z wieloma sankcjami, mimo że działały w interesie publicznym. Represje spotykają również informujących o nieprawidłowościach w znacznie mniejszej skali. W dyskursie prawniczym takie osoby nazywa się sygnalistami. Podnosi się, że - przy zachowaniu określonych kryteriów - powinna im przysługiwać ochrona. Jednocześnie orzecznictwo Europejskiego Trybunału Praw Człowieka (ETPC) jednoznacznie wiąże ujawnianie informacji o nieprawidłowościach z ochroną wolności wypowiedzi.

Celem niniejszego artykułu będzie ustalenie, w jakich warunkach osobie ujawniajaccej tego rodzaju informacje przysługuje status sygnalisty oraz analiza związków ochrony sygnalistów z wolnością wypowiedzi, a także próba rozważenia, czy na państwie ciążą obowiązki objęcia sygnalistów ochroną.

\section{POJĘCIE SYGNALISTY}

Przed przejściem do szczegółowych rozważań należy wyjaśnić, że - w najbardziej ogólnym znaczeniu - sygnalistą jest osoba, która mając informacje o nieprawidłowym postępowaniu innych podmiotów, informuje o tym odpowiednie organy władzy publicznej lub opinię publiczną. Osobę taką często określa się angielską nazwą whistleblower, pierwotnie oznaczająca policjanta, który dmuchał w gwizdek podczas pogoni za sprawca przestępstwa ${ }^{1}$. W polskiej literaturze używa się zamiennie terminów: „whistleblower”, „sygnalista” i „demaskator”.

\footnotetext{
1 Świątkowski (2015): 11.

2 Ploszka (2014): 12.
} 
Pojęcia whistleblower, sygnalisty i demaskatora są pojęciami języka prawniczego, nie są natomiast pojęciami języka prawnego, ponieważ nie posługuje się nimi krajowy ustawodawca ${ }^{3}$. Jednakże w ratyfikowanych przez Rzeczpospolitą Polską umowach międzynarodowych znajdują się przepisy dotyczące ochrony sygnalistów, na które warto w tym miejscu zwrócić uwagę.

Zgodnie z art. 33 Konwencji Narodów Zjednoczonych przeciwko korupcji ${ }^{4}$ każde państwo strona rozważy włączenie do swego wewnętrznego systemu prawnego odpowiednich środków w celu zapewnienia ochrony przed jakimkolwiek nieuzasadnionym działaniem każdej osobie, która zgłasza w dobrej wierze i na racjonalnych podstawach właściwemu organowi wszelkie zdarzenia związane z przestępstwami ustanowionymi zgodnie z niniejszą Konwencja. Nadto art. 9 Cywilnoprawnej konwencji o korupcji ${ }^{5}$ stanowi, że każda strona zapewni w swoim prawie wewnętrznym odpowiednią ochronę przed wszelkimi nieuzasadnionymi sankcjami wobec pracowników, którzy mając uzasadnione podstawy, aby podejrzewać, że doszło do korupcji, zgłaszają w dobrej wierze swoje podejrzenia odpowiednim osobom lub władzom. Rozwiązania rekomendowane w cytowanych przepisach nie zostały jednak wdrożone do polskiego porządku prawnego przez wprowadzenie szczególnych przepisów chroniących sygnalistów ${ }^{6}$.

Zazwyczaj sygnalista jest pracownik, były pracownik, osoba samozatrudniona czy członek organizacji (państwowej, samorządowej, społecznej). Zgłaszane przezeń nieprawidłowości mogą w szczególności polegać na postępowaniu niezgodnym z przepisami prawa, procedurami wewnętrznymi, zasadami współżycia społecznego lub na narażaniu interesu publicznego ${ }^{7}$. Nie ma przy tym znaczenia, czy nieprawidłowości występują u prywatnego czy publicznego pracodawcy (innego podmiotu), o czym będzie jeszcze mowa niżej.

Nadto należy zwrócić uwagę na dyrektywę Parlamentu Europejskiego i Rady w sprawie osób zgłaszających naruszenia prawa Unii ${ }^{8}$. W art. 4 dyrektywy prawodawca unijny wskazuje, że jej przepisy stosuje się do osób dokonujących zgłoszenia, pracujących w sektorze prywatnym lub publicznym, które uzyskały informacje na temat naruszeń w kontekście związanym z praca. Nie ma przy tym znaczenia, czy w momencie dokonywania istniał między sygnalistą a jego pracodawcą stosunek pracy. Co warte podkreślenia, dyrektywa

\footnotetext{
${ }^{3}$ Ustawodawca używa terminu „sygnalista” w innym znaczeniu - do określenia osoby wykonującej czynności specjalistyczne w ruchu zakładu górniczego, na co zwraca uwagę Ploszka (2014): 12. Zob. art. 53 ust. 5 pkt 1 lit. c ustawy z 9 czerwca 2011 r. - Prawo geologiczne i górnicze (t.jedn.: Dz. U. 2017, poz. 2126 ze zm.).

${ }^{4}$ Konwencja Narodów Zjednoczonych przeciwko korupcji, przyjęta przez Zgromadzenie Ogólne Narodów Zjednoczonych dnia 31 października 2003 r., Dz. U. 2007, Nr 84, poz. 563 (dalej jako: KPK).

${ }_{5}^{5}$ Cywilnoprawna konwencja o korupcji, sporządzona w Strasburgu dnia 4 listopada 1999 r., Dz. U. 2004, Nr 244, poz. 2443.

${ }^{6}$ Wojciechowska-Nowak (2015): 36.

${ }^{7}$ Wujczyk (2014): 114.

${ }^{8}$ Dyrektywa Parlamentu Europejskiego i Rady (UE) 2019/1937 z 23 października 2019 r. w sprawie ochrony osób zgłaszających naruszenia prawa Unii, Dz. Urz. UE L 2019, nr 305: 17.
} 
rozszerza zakres stosowania środków ochrony przysługujących sygnaliście także na osoby pomagające w dokonaniu zgłoszenia; osoby trzecie powiązane z sygnalista, które mogą doświadczyć działań odwetowych w kontekście związanym z praca, oraz podmioty prawne, które stanowią własność osoby dokonującej zgłoszenia, dla których taka osoba pracuje lub które są w inny sposób $\mathrm{z}$ nią powiązane $\mathrm{w}$ kontekście związanym z pracą.

W doktrynie wskazano, że o uznaniu danej osoby za sygnalistę przesądza łączne spełnienie następujących kryteriów: odkrycie przez sygnalistę nieprawidłowości; zgłoszenie ich właściwemu podmiotowi, motywowane „szlachetnymi pobudkami” (dobrem pracodawcy, ochroną innych osób) oraz zagrożenie sytuacji sygnalisty, wynikające z ujawnienia nieprawidłowości. Podkreśla się przy tym, że sygnalista powinien w pierwszej kolejności poinformować o naruszeniach pracodawcę, a dopiero brak reakcji z jego strony uzasadnia upublicznienie informacji o nieprawidłowościach ${ }^{9}$. Sankcje, które grożą sygnaliście w związku z ujawnieniem nieprawidłowości, polegają najczęściej na rozwiązaniu umowy o pracę lub nałożeniu kar pieniężnych przez pracodawcę czy utracie premii. Problematyka sygnalizacji budzi zatem szczególne zainteresowanie doktryny prawa pracy ${ }^{10}$.

Z wyżej wymienionymi kryteriami można się zasadniczo zgodzić, aczkolwiek wypada do nich zgłosić dwa zastrzeżenia. Po pierwsze, zbadanie rzeczywistej motywacji sygnalisty może okazać się niezwykle trudne, a niekiedy - niemożliwe. Co więcej, przyczyny zawiadomienia o nieprawidłowościach mogą być złożone, zarówno „szlachetne”, jak i zgoła niegodziwe (np. osobista niechęć czy oczekiwanie korzyści finansowych). Wydaje się, że współwystępowanie pozytywnie i negatywnie ocenianych pobudek nie powinno wpływać na kwalifikacje danej osoby jako sygnalisty, a jedynie na stopień ochrony przyznawanej po zastosowaniu sankcji przez pracodawcę. Po drugie, w niektórych sytuacjach zgłoszenie naruszeń w ramach procedur wewnętrznych (bezpośredniemu przełożonemu lub kierownikowi) może być niecelowe - zwłaszcza gdy nieprawidłowości są udziałem przełożonych. Wówczas uzasadnione będzie upublicznienie informacji o naruszeniach, co nie powinno powodować utraty ochrony, jaka przysługuje sygnaliście.

Czynność zgłaszania nieprawidłowości określa się mianem sygnalizacji. Należy zauważyć, że tego pojęcia używa się również wobec zawiadamiania organów powołanych do nadzoru lub kontroli przez prokuratora lub sąd w toku postępowania karnego $\mathrm{w}$ razie stwierdzenia poważnych uchybień w działaniu instytucji państwowej, samorządowej lub społecznej na podstawie przepisów $\mathrm{KPK}^{11}$. Ta instytucja karnoprocesowa nie będzie jednak przedmiotem dalszych rozważań z uwagi na to, że dotyczy zgłaszania nieprawidłowości przez osoby i organy do tego powołane z mocy przepisów prawa.

${ }^{9}$ Wujczyk (2014): 114.

${ }_{10} \mathrm{~W}$ polskiej literaturze tematykę sygnalizacji z punktu widzenia prawa pracy podejmuja m.in.: Świątkowski (2015); Wujczyk (2014); Jaśkowski (2019).

11 Szerzej na ten temat: Karaźniewicz (2015): 66-75. 


\section{SYGNALIZACJA JAKO KORZYSTANIE Z WOLNOŚCI POZYSKIWANIA I ROZPOWSZECHNIANIA INFORMACJI}

Jak już wcześniej wskazano, problematyka sygnalizacji pozostaje w oczywistej sferze zainteresowania prawa pracy. Należy jednak zwrócić uwagę, że potrzeba zapewnienia ochrony sygnalistów wynika z przysługującej im wolności wypowiedzi.

W art. 54 Konstytucji RP, stanowiącym o wolności wypowiedzi, ustrojodawca wskazał na trzy odrębne, lecz powiązane ze sobą wolności jednostki: wolność wyrażania swoich poglądów, wolność pozyskiwania informacji oraz wolność rozpowszechniania informacji ${ }^{12}$. Trzeba również zwrócić uwagę na przepis art. 10 Konwencji o ochronie praw człowieka i podstawowych wolności ${ }^{13}$, który stanowi o prawie do wolności wyrażania opinii - obejmuje ono wolność posiadania poglądów oraz otrzymywania i przekazywania informacji i idei ${ }^{14}$.

Sygnalizacja - zwłaszcza dotycząca przypadków korupcji czy innych nadużyć ze strony urzędników państwowych - powinna być objęta szczególna ochroną dlatego, że w szczególnym interesie publicznym jest, by tego rodzaju nieprawidłowości wyszły na jaw. Innymi słowy, przedmiot wypowiedzi sygnalisty uzasadnia szczególny poziom ochrony ${ }^{15}$.

Ów interes publiczny wyraża się w szczególności w zapewnieniu realizacji zasady transparentności (jawności) życia publicznego ${ }^{16}$. We współczesnym państwie demokratycznym tę zasadę utożsamia się w szczególności z prawem szerokiego dostępu do informacji na temat działalności władz publicznych, jak również osób je reprezentujących. Powzięcie wiadomości co do sposobu funkcjonowania organów państwa jest zaś niezbędnym warunkiem sprawowania obywatelskiej kontroli nad władza publiczną ${ }^{17}$. Uzyskanie przez obywateli informacji o nieprawidłowościach $\mathrm{w}$ tym obszarze jest możliwe szczególnie za pośrednictwem sygnalistów, co uzasadnia przyznanie im silnej ochrony przed konsekwencjami ujawnienia przedmiotowych informacji. Sygnalista jest najczęściej osoba pozostająca w stosunku pracy. Należy więc w tym miejscu rozważyć, czy z tego względu jego wolność wypowiedzi doznaje ograniczeń, a jeśli tak - to w jakim zakresie.

Stosunek pracy jest stosunkiem horyzontalnym. Przez to ostatnie pojęcie rozumie się „stosunek prawny typu zobowiązaniowego powstały między dwoma podmiotami prywatnymi, które względem siebie pozostają w relacji równorzędnej”"18. Zwraca się wprawdzie uwagę, że relacja pracodawcy i pracownika

${ }^{12}$ Sadomski (2016): 1282.

${ }^{13}$ Dz. U. 1993, Nr 61, poz. 284 (dalej jako: EKPC).

${ }^{14}$ Podaję tekst EKPC za oficjalnym tłumaczeniem z Dziennika Ustaw. W literaturze wskazuje się jednak na brak precyzji w tłumaczeniu tekstu EKPC na język polski - zob. Nowicki (2013): 762.

15 Voorhof (2012): 30-31 i cyt. tam orzecznictwo ETPC.

${ }^{16} \mathrm{Na}$ temat zasady jawności życia publicznego oraz jej miejsca w polskim porządku konstytucyjnym szerzej: Osowski, Wilk (2015): 27-29.

17 Jabłoński (2018): 40-46.

${ }_{18}$ Florczak-Wątor (2014): 34-35. 
jest w znacznej części kształtowana przez przepisy prawa powszechnie obowiązującego o charakterze imperatywnym, co powoduje, że prawa pracy nie można traktować jako gałęzi prawa prywatnego ${ }^{19}$. Jednakże podkreśla się, że niewątpliwie pracownik pozostaje zasadniczo słabszą stroną stosunku prawnego, co stanowi uzasadnienie ingerencji w ten stosunek ze strony państwa ${ }^{20}$, lecz nie zmienia jego horyzontalnego charakteru ${ }^{21}$.

Powstaje zatem pytanie, czy w stosunku pracy zmienia się zakres wolności wypowiedzi. Ten problem rozważał już Europejski Trybunał Praw Człowieka (ETPC) na gruncie art. 10 EKPC, stwierdzając, że przepis ten odnosi się również do stosunków wynikajacych z prawa prywatnego, w tym - stosunków pracy $^{22}$. Co więcej, ETPC podkreślił, że w niektórych przypadkach państwo ma pozytywny obowiązek chronić prawo do swobody wypowiedzi przed zamachami również ze strony podmiotów prywatnych ${ }^{23}$. Teza wyrażona przez ETPC została następnie podtrzymana w kolejnych orzeczeniach strasburskiego trybunału $^{24}$, jak również zaaprobowana przez sądy polskie ${ }^{25}$.

Z punktu widzenia przedmiotu niniejszego artykułu, spośród wymienionych składowych wolności wypowiedzi, na uwagę zasługuje zwłaszcza wolność rozpowszechniania informacji. W literaturze wskazuje się że przez „rozpowszechnianie informacji” należy rozumieć „udostępnianie zebranych danych osobom trzecim - fizycznym lub prawnym - ale tylko indywidualnie wybranym przez rozpowszechniajacego, jak i upowszechnianie tych danych, czyli podawanie do wiadomości publicznej, kierowanie do niezindywidualizowanych adresatów ${ }^{26}$ ". Warto zauważyć, że sygnalizacja mieści się w ramach tak rozumianego rozpowszechniania informacji, i to niezależnie od przyjętego sposobu informowania o nieprawidłowościach. Zarówno w sytuacji sygnalizacji „wewnętrznej” - to jest za pośrednictwem bezpośredniego przełożonego lub pracodawcy, jak i sygnalizacji „zewnętrznej” - to jest za pośrednictwem organów ścigania, związków zawodowych czy środków masowego przekazu ${ }^{27}$, sygnalista będzie korzystał z wolności rozpowszechniania informacji. Rozpowszechnianie informacji przez sygnalistę może przy tym polegać na przykład na złożeniu ustnej lub pisemnej skargi, sporządzeniu ulotki lub plakatu informującego o naruszeniach czy zawiadomieniu organów ścigania ${ }^{28}$.

\footnotetext{
19 Wyrok TK z 13 września 2005 r., K 38/04, OTK-A 2005, nr 8, poz. 92.

20 Zob. np. Florek (2016).

21 Zob. zwłaszcza: Sobczyk (2015): 117.

${ }_{22}$ Wyrok ETPC z 29 lutego 2000 r. w sprawie Fuentes Bobo przeciwko Hiszpanii, skarga nr 39293/98: $\$ 38$.

${ }^{23}$ Nowicki (2005): 1008. Por. w tym zakresie Kamiński (2010): 586, który podkreśla, że w omawianej sprawie ETPC nie wypowiedział się szczegółowo co do zakresu takich przypadków, w których na państwie ciążyłyby obowiązki pozytywne.

${ }^{24}$ Np. wyrok Wielkiej Izby ETPC z 12 września 2011 r. w sprawie Palomo Sanchez $i$ inni przeciwko Hiszpanii, połączone skargi nr 28955/06, 28957/06, 29859/06 i 28964/06: § 59.

25 Np. wyrok SN z 21 sierpnia 2012 r., II PK 19/12.

26 Biłgorajski (2013): 201.

27 Na temat sygnalizacji „wewnętrznej” i „zewnętrznej” zob. np. Świątkowski (2015): 17.

28 Por. Ploszka (2014): 14.
} 


\section{STANDARDY OCHRONY SYGNALISTÓW WYPRACOWANE W ORZECZNICTWIE STRASBURSKIM}

W związku z tym, że sygnalizacja stanowi formę realizacji wolności wypowiedzi, stosowanie sankcji wobec sygnalistów podlega ocenie także z perspektywy dopuszczalności ograniczeń tej wolności. Szczególną doniosłość ma w tym zakresie orzecznictwo ETPC, którego orzeczenia mają wpływ na kształtowanie się standardu ochrony sygnalistów także w sądach polskich ${ }^{29}$.

Kluczowe znaczenie dla wypracowania standardu strasburskiego miało orzeczenie z 2008 r. w sprawie Guja przeciwko Mołdawii ${ }^{30}$. Był to pierwszy wyrok ETPC, w którym wprost odniesiono się do ochrony sygnalistów ${ }^{31}$. Został on wydany w składzie Wielkiej Izby ETPC, której sprawa została przekazana w wyniku zrzeczenia się właściwości przez Izbę na podstawie art. 30 EKPC. Przesłanką zastosowania tego trybu jest pojawienie się poważnego zagadnienia dotyczącego interpretacji EKPC. Z powyższych względów wyrok w sprawie Guja przeciwko Mołdawii wymaga szerszego omówienia.

Podstawę faktyczną skargi stanowiły wydarzenia ze stycznia 2003 r.: prezydent Mołdawii wygłosił przemówienie, w którym poruszył problem presji wywieranej ze strony wysoko postawionych urzędników na organy ścigania w sprawach karnych. Wezwał funkcjonariuszy do walki z korupcją oraz do nieulegania naciskom. Wystapienie zostało szeroko opisane przez media. Kilka dni po przemówieniu prezydenta skarżący - kierujący departamentem prasowym prokuratora generalnego - przekazał prasie dwa listy, które wpłynęły do prokuratury.

Pierwszy z ujawnionych dokumentów pochodził od czterech policjantów i dotyczył żądania ochrony przed ściganiem za czyny związane z bezprawnym pozbawieniem wolności. List trafił do Prokuratury Generalnej - przekazał go zastępca przewodniczacego mołdawskiego parlamentu i został opatrzony jego komentarzem, w którym znalazła się „osobista prośba o interwencję i rozwiązanie sprawy zgodnie z prawem" oraz pytanie, czy prokurator walczy z przestępcami czy z policją. Drugi z przekazanych przez skarżącego dokumentów został sporządzony przez wiceministra spraw wewnętrznych. Informował w nim prokuratora generalnego o tym, że jeden z czterech policjantów był już wcześniej skazany między innymi za wymuszenie zeznań przy użyciu przemocy, a po amnestii został przywrócony do pracy w policji. Żaden z ujawnionych listów nie został przez ich autorów ani przez skarżącego oznaczony jako korespondencja poufna.

${ }^{29} \mathrm{Na}$ temat roli ETPC w kształtowaniu standardów dotyczących ochrony wypowiedzi w Polsce zob. Bychawska-Sinarska (2017): 34 n. Orzecznictwo ETPC dotyczące sygnalistów jest szczególnie brane pod uwagę w judykaturze SN - zob. np. wyrok SN z 25 listopada 2014 r., I PK 98/14, ale także w orzecznictwie sądów powszechnych - zob. np. wyrok SR w Białymstoku z 29 stycznia 2016 r., VI P 322/15.

${ }^{30}$ Wyrok Wielkiej Izby ETPC z 12 lutego 2008 r. w sprawie Guja przeciwko Mołdawii, skarga nr 14277/04.

31 Ploszka (2014): 14. 
W następstwie ujawnienia korespondencji gazeta „Jurnal de Chişinău” opublikowała artykuł, w którym poparto apel prezydenta i potępiono praktyki korupcyjne oraz naciski na prokuraturę. Gazeta przedrukowała w całości treść ujawnionych przez skarżącego listów, podając je jako przykład nagannych praktyk. Skarżący przyznał, że ujawnił korespondencję, jednak stał na stanowisku, że jego działanie było zgodne z postulatami prezydenta Mołdawii i miało na celu poprawę wizerunku jego pracodawcy. Konsekwencją publikacji było zwolnienie skarżącego z pracy. Uzasadniając tę decyzję, wskazano, że ujawnione listy objęto tajemnica, a skarżący zaniechał konsultacji z kierownictwem prokuratury generalnej, czym naruszył wewnętrzny regulamin. W przekazie medialnym podano informację, że zwolnienie skarżącego było spowodowane bezpośrednim żądaniem zainteresowanych polityków ${ }^{32}$. Sądy krajowe nie uwzględniły środków zaskarżenia wnoszonych od decyzji o rozwiązaniu stosunku pracy.

Europejski Trybunał Praw Człowieka, rozpoznając skargę wniesioną w wyżej opisanych okolicznościach, stwierdził przede wszystkim, że w sprawie spełnione zostały dwie z przesłanek dopuszczalności ograniczeń wolności wypowiedzi: ingerencja była przewidziana przez prawo (prescribed by law) oraz służyła uprawnionemu celowi (legitimate aim) - zapobieżeniu ujawnienia informacji poufnych. Trybunał badał w szerszym zakresie spełnienie przesłanki konieczności ${ }^{33}$ ingerencji w demokratycznym społeczeństwie. Trybunał podkreślił, że z jednej strony funkcjonariuszowi publicznemu nie można odmawiać wolności wypowiedzi, jednakże pozostawanie w służbie publicznej rodzi obowiązek lojalności i dyskrecji wobec pracodawcy ${ }^{34}$. Z tego obowiązku wywodzi się między innymi konieczność zachowania w tajemnicy informacji, które zostały uznane za poufne lub tajne ${ }^{35}$. Dochowanie tajemnicy nie może być jednak rozumiane jako obowiązek o charakterze absolutnym, a sygnalizacja powinna być objęta ochroną zwłaszcza wówczas, gdy sygnalista jest jedyną albo jedną z niewielu osób wiedzących o nieprawidłowościach ${ }^{36}$.

Trybunał dostrzegł precedens w sprawie Guja przeciwko Mołdawii w tym, że funkcjonariusz publiczny ujawnił opinii publicznej informacje przeznaczone do użytku wewnętrznego. Można więc działania skarżącego zakwalifikować jako sygnalizację zewnętrzna. ETPC podkreślił, że pierwszeństwo powinna mieć co do zasady sygnalizacja wewnętrzna, aczkolwiek zwrócił uwagę na istotny wyjątek: gdy zgłoszenie nieprawidłowości przełożonemu byłoby „oczywiście niepraktyczne” (clearly impracticable), w ostateczności dopuszczalne jest ujawnienie informacji opinii publicznej ${ }^{37}$.

32 Kamiński (2010): 241.

${ }^{33} \mathrm{~W}$ literaturze wskazuje się, że właściwym tłumaczeniem sformułowania „necessary in a democratic society” winno być „konieczne w demokratycznym społeczeństwie” - zob. Kamiński (2010): 27. Polska wersja EKPC, opublikowana w Dzienniku Ustaw, posługuje się jednak przymiotnikiem „niezbędny”.

${ }^{34}$ Guja przeciwko Mołdawii: $§ 70$.

${ }^{35}$ Guja przeciwko Mołdawii: $\$ 71$.

36 Guja przeciwko Mołdawii: $§ 72$.

37 Guja przeciwko Mołdawii: § 73; zob. również wyrok ETPC z 21 czerwca 2016 r. w sprawie Soares przeciwko Portugalii, skarga nr 79972/12: § 47, w którym Trybunał stwierdził, że nie- 
W literaturze podkreśla się, że omawiane orzeczenie wyróżnia się precyzją na tle judykatury ETPC, doprecyzowuje bowiem okoliczności, w których sygnalistę należy objąć ochroną ${ }^{38}$ i które należy wziąć pod uwage przy ocenie proporcjonalności ingerencji w wolność wypowiedzi. Wskazane przez ETPC warunki powinny być spełnione kumulatywnie, aby sygnalista był objęty ochrona.

$\mathrm{Na}$ pierwszy plan wysuwa się kwestię istnienia interesu publicznego w ujawnieniu nieprawidłowości, który - w odniesieniu do wyjawienia informacji poufnych - musi być szczególnie silny. Następnie należy wziać pod uwagę wiarygodność przekazanych informacji, a także ocenić, czy ewentualna szkoda, jaką władze publiczne moga ponieść w następstwie ujawnienia informacji, nie przeważa interesu publicznego w uzyskaniu tej informacji ${ }^{39}$. Czwartym wymogiem stawianym przez ETPC jest dobra wiara po stronie sygnalisty działanie $\mathrm{z}$ innych powodów niż osobista uraza czy chęć zysku ${ }^{40}$. Ostatnim z kryteriów oceny jest sankcja nałożona na sygnalistę ${ }^{41}$, przy czym zwraca się uwage na brak precyzji Trybunału w tym fragmencie uzasadnienia wyroku, nie wynika bowiem z niego, czy przy ocenie proporcjonalności ingerencji należy brać pod uwagę samą surowość sankcji czy też jej możliwe skutki ${ }^{42}$.

W omawianej sprawie Trybunał dokonał oceny proporcjonalności ingerencji z zastosowaniem wymienionych kryteriów, co doprowadziło do stwierdzenia, że doszło do naruszenia art. 10 EKPC. W szczególności ETPC za uzasadnione uznał ujawnienie informacji mediom, nie istniały bowiem żadne wewnętrzne procedury pozwalające na zgłoszenie nieprawidłowości, a dotychczasowe postępowanie przełożonych dawało podstawy do przyjęcia, że ulegli oni naciskom politycznym $^{43}$. Istnienie interesu publicznego oraz wiarygodność informacji przekazanych przez skarżącego nie budziły w sprawie wątpliwości. Trybunał zaakcentował także, że zastosowana sankcja była najsurowszą z możliwych, co w oczywisty sposób dotknęło skarżącego, ale również potencjalnie wpływa na pozostałych pracowników sektora publicznego i może wywierać efekt mrożący - to jest powstrzymywać ich przed ujawnianiem nieprawidłowości ${ }^{44}$.

Europejski Trybunał Praw Człowieka dokonał uzupełnienia omówionego wyżej standardu w orzeczeniu w sprawie Heinisch przeciwko Niemcom ${ }^{45}$. Skarżąca pracowała jako pielęgniarka w domu opieki dla osób starszych. Była zatrudniona przez spółkę z ograniczoną odpowiedzialnościa, w której większościowym udziałowcem był kraj związkowy (land) Berlin. Skarżąca wielokrotnie zwracała przełożonym uwage na braki kadrowe oraz przepracowanie

skorzystanie z istniejącej możliwości sygnalizacji wewnętrznej w Gwardii Narodowej pozbawia skarżącego ochrony przewidzianej dla sygnalistów.

38 Kamiński (2010): 242-243; zob. również: Ploszka (2014): 15.

${ }^{39}$ Guja przeciwko Mołdawii; § 75-76.

40 Guja przeciwko Mołdawii: $\$ 77$.

41 Guja przeciwko Mołdawii: $§ 78$.

${ }^{42}$ Kamiński (2010): 242-243.

43 Guja przeciwko Mołdawii: § 81-83.

${ }_{44}$ Guja przeciwko Mołdawii: $§ 95$.

45 Wyrok ETPC z 21 lipca 2011 r. w sprawie Heinisch przeciwko Niemcom, skarga nr 28274/08. 
personelu medycznego. Zarzuty zostały potwierdzone w toku kontroli przeprowadzonej przez komisję Funduszu Ubezpieczeń Zdrowotnych, która stwierdziła niezadowalający poziom opieki nad pacjentami ośrodka. Pomimo kontroli sytuacja w domu opieki nie uległa zmianie, co skłoniło skarżącą do wystapienia do pracodawcy - za pośrednictwem profesjonalnego pełnomocnika - z żądaniem wyjaśnienia sytuacji i zapewnienia należytego poziomu opieki pacjentom. Wobec braku reakcji spółki skarżąca złożyła zawiadomienie o możliwości popełnienia przestępstwa przez narażenie zdrowia i życia podopiecznych. Krótko po złożeniu tego zawiadomienia skarżąca została zwolniona z pracy za wypowiedzeniem; jako przyczynę zwolnienia wskazano częste nieobecności związane z chorobą. Spotkało się to z niezadowoleniem skarżącej, dlatego rozpowszechniła ulotkę, w której nazwała zwolnienie próbą zastraszenia i politycznym odwetem. Z treści tej ulotki były pracodawca skarżącej dowiedział się o toczącym się postępowaniu karnym i rozwiązał stosunek pracy bez wypowiedzenia. Sądy krajowe nie uwzględniły środków zaskarżenia wnoszonych od decyzji o rozwiązaniu stosunku pracy, a postępowanie karne wszczęte z zawiadomienia skarżącej zostało umorzone.

Rozpoznając skargę, ETPC przypomniał, że sygnalizacja powinna podlegać ochronie pod pewnymi warunkami, określonymi przede wszystkim w wyroku w sprawie Guja przeciwko Mołdawii ${ }^{46}$. We wstępnej części uzasadnienia orzeczenia powtórzono nadto tezę, że państwo ma pozytywny obowiązek ochrony wolności wypowiedzi także w sferze stosunków horyzontalnych ${ }^{47}$.

$\mathrm{Na}$ tle opisanego wyżej stanu faktycznego rysuje się jedna zasadnicza różnica między sprawą Guja przeciwko Motdawii a Heinisch przeciwko Niemcom. Mianowicie w tej ostatniej sprawie pracodawca nie był podmiot prawa publicznego, a skarżąca nie była urzędnikiem ani członkiem korpusu służby cywilnej. Trybunał stwierdził, że w takiej sytuacji pracownik również ma obowiązek lojalności wobec pracodawcy oraz ochrony jego reputacji i interesu gospodarczego, choć te powinności nie są tak silnie eksponowane, jak w przypadku urzędników służby cywilnej ${ }^{48}$. Przy ocenie proporcjonalności ingerencji w wolność wypowiedzi sygnalisty należy wziąć pod uwagę indywidualnie (konkretnie) ustalony zakres obowiązku lojalności pracownika wobec pracodawcy oraz interesy pracodawcy, które pozostaja w konflikcie z prawami pracownika ${ }^{49}$.

Niewatpliwie jednak najbardziej doniosłym elementem orzeczenia w sprawie Heinisch przeciwko Niemcom jest potwierdzenie, iż sygnalizacja zasługuje na ochronę także wówczas, gdy sygnalista jest pracownik podmiotu prywatnego ${ }^{50}$. Do takich sygnalistów znajdują pełne zastosowanie kryteria wypracowane w orzeczeniu w sprawie Guja przeciwko Mołdawii, z zastrzeżeniem odmiennego zakresu obowiązku lojalności, o czym była mowa wyżej.

\footnotetext{
${ }^{46}$ Heinisch przeciwko Niemcom: $§ 63$.

${ }^{47}$ Heinisch przeciwko Niemcom: $§ 44$.

48 Heinisch przeciwko Niemcom: § 64-65.

49 Heinisch przeciwko Niemcom: § 64-65.

50 Zwraca na to uwage Ploszka (2014): 17.
} 
W doktrynie niemieckiej podkreślono, że uzasadnienie wyroku w sprawie Heinisch może nasuwać przypuszczenie, że istnieje różny zakres ochrony $\mathrm{w}$ zależności od tego, czy pracownik jest zatrudniony w podmiocie publicznym, w spółce prawa handlowego z dominującym udziałem państwa, czy też w podmiocie stricte prywatnym. Jednakże ETPC nie wyraził poglądu, by wolność wypowiedzi pracownika sektora prywatnego była bardziej ograniczona niż w sektorze publicznym. Te dwie sytuacje różnią się interesem, jaki ma państwo w ujawnieniu nieprawidłowości, jednakże - jeśli podmiot prywatny narusza prawa zagwarantowane w EKPC - jak w omawianej sprawie: prawo do ochrony zdrowia i życia - to w ostateczności obowiązek ochrony tego prawa spoczywa na państwie. W ramach tak rozumianego obowiązu państwa mieści się więc również ochrona sygnalisty, który ujawnił zagrożenie czy naruszenie prawa innego podmiotu ${ }^{51}$.

Europejski Trybunał Praw Człowieka we wskazanych orzeczeniach ustanowił dość czytelny standard ochrony sygnalistów i wskazał, jakie okoliczności powinny być brane pod uwagę przy ocenie dopuszczalności ingerencji w wolność wypowiedzi. W kolejnych - nielicznych - orzeczeniach dotyczących omawianej problematyki Trybunał nie odstępował od ustalonej linii ${ }^{52}$.

Jednocześnie należy dostrzec, że w żadnym z wyroków nie ujęto precyzyjnej definicji sygnalisty ${ }^{53}$. Trzeba jednak odnotować w tym miejscu niedawny wyrok Wielkiej Izby w sprawie bośniackiej ${ }^{54}$, dotyczącej wyborów na stanowisko dyrektora wieloetnicznej rozgłośni radiowej. W liście do lokalnych władz zostały ujawnione okoliczności podważające kwalifikacje moralne serbskiej kandydatki na to stanowisko i wskazujące na jej silną niechęć wobec bośniackiej mniejszości. Co istotne, list nie pochodził od pracownika radia, lecz był wyrazem stanowiska kilku organizacji zrzeszającej Bośniaków, które następnie były skarżącymi w postępowaniu przed ETPC. Trybunał podkreślił, że sprawa nie dotyczy problematyki sygnalizacji, skarżące organizacje nie miały bowiem obowiązu lojalności, powściąliwości ani dyskrecji wobec rozgłośni radiowej (pracodawcy). Nadto skarżący nie mieli wyłącznego dostępu do ujawnionej informacji, a jedynie działali jako pośrednicy w przekazaniu informacji do publicznej wiadomości. Z tych względów ETPC nie rozważał przedmiotowej sprawy w kontekście sygnalizacji ${ }^{55}$.

Poza opisaną wyżej sprawą w dotychczasowym orzecznictwie kwestia podmiotowego zakresu ochrony sygnalistów była podnoszona jedynie obiter dic$t a$, i to od strony negatywnej. W kilku orzeczeniach ETPC podkreślił, że dla kwalifikacji danej osoby jako sygnalisty ma znaczenie jego motywacja - jeżeli ujawnia ona informacje z powodów osobistych, w szczególności zemsty wo-

51 Schubert (2011): 761.

${ }^{52}$ Zob. wyrok ETPC z 8 stycznia 2013 r. w sprawie Bucur $i$ Toma przeciwko Rumunii, skarga nr 40238/02.

53 Ploszka (2014): 18.

${ }^{54}$ Wyrok Wielkiej Izby ETPC z 27 czerwca 2017 r. w sprawie Medžlis Islamske Zajednice Brčko i inni przeciwko Bośni i Hercegowinie, skarga nr 17224/11.

${ }_{55}$ Medžlis Islamske Zajednice Brčko i inni przeciwko Bośni: § 80. 
bec określonej osoby, nie może zostać uznany za sygnalistę ${ }^{56}$. W omawianych sprawach motywacja poszczególnych osób była jednak relatywnie łatwa do ustalenia i wynikała z całokształtu okoliczności sprawy. Trybunał nie zmierzył się jednak dotychczas ze sprawa, w której motywacja osoby ujawniającej nieprawidłowości byłaby złożona, a jednocześnie pozostałe okoliczności wskazywałyby na konieczność rozważenia objęcia tej osoby ochroną właściwą dla sygnalistów. Z tego względu należy uznać, że przyczyna ujawnienia nieprawidłowości jest istotna dla kwalifikacji danej osoby jako sygnalisty, nie jest to jednak okoliczność decydująca.

\section{OBOWIĄZKI POZYTYWNE PAŃSTWA}

Należy zauważyć, że przytoczone orzeczenia ETPC wpisują się w refleksję nad zwiększaniem roli państwa jako gwaranta praw i wolności oraz oczekiwania aktywnej postawy organów władzy (także sąów) w przypadku, gdy to podmioty prywatne ingerują $\mathrm{w}$ wolności gwarantowane konstytucyjnie czy konwencyjnie ${ }^{57}$. Zwraca się uwagę, że adresatem obowiązku pozytywnego jest państwo, a zatem na jego naruszenie jednostka może powoływać się przed sądem dopiero wówczas, gdy zastosowane przez państwo środki $\mathrm{w}$ formie ustawy czy działań administracyjnych - nie zapewniły wystarczajacej ochrony ${ }^{58}$.

Jak już wcześniej podkreślono, istnieją sytuacje, w których na państwie spoczywa obowiązek zapewnienia wolności wypowiedzi w stosunkach horyzontalnych. Pogląd ten wyraził ETPC w wyroku w sprawie pracowniczej Fuentes Bobo przeciwko Hiszpanii - jednakże nie rozwinął go szerzej, w rozpatrywanej sprawie bowiem kwestia obowiązków ochronnych nie miała ona zasadniczego znaczenia.

Należy stwierdzić, że sygnalizacja powinna być objęta ochroną ze strony państwa z uwagi na gwarantowana konstytucyjnie i konwencyjnie wolność wypowiedzi. Sygnalizacja sprzyja bowiem realizacji tych wartości, dla których proklamowana została wolność wypowiedzi. W wielokrotnie cytowanym orzeczeniu w sprawie Handyside przeciwko Wielkiej Brytanii ETPC stwierdził, że „Swoboda wypowiedzi jest jednym z filarów demokratycznego społeczeństwa, podstawa jego rozwoju i warunkiem samorealizacji jednostki. [...] Nie może obejmować wyłącznie informacji i poglądów odbieranych przychylnie albo postrzeganych jako nieszkodliwe lub obojętne, ale i takie, które obrażaja, oburzaja lub wprowadzają niepokój w państwie albo w jakiejś grupie społeczeń-

${ }^{56}$ Zob. wyroki ETPC: z 19 stycznia 2016 r. w sprawie Aurelian Oprea przeciwko Rumunii, skarga nr 12138/08: § 87; z 13 stycznia 2015 r. w sprawie Rubins przeciwko Eotwie, skarga nr 79040/12: § 86-89; z 17 września 2015 r. w sprawie Langner przeciwko Niemcom, skarga nr 14464/11: $\$ 47$.

57 Zob. Florczak-Wątor (2014): 49-52. Na ten temat w kontekście wolności wypowiedzi zob. Florczak-Wątor (2018): 164-169.

58 Schubert (2011): 761. 
stwa. Takie sa wymagania pluralizmu, tolerancji i otwartości, bez których demokratyczne społeczeństwo nie istnieje"59.

We współczesnym, demokratycznym społeczeństwie pożądane jest, by obywatele mieli dostęp do informacji na temat sposobu działania władzy publicznej ${ }^{60}$. Dzięki ujawnieniu nieprawidłowości społeczeństwo może kształtować swoje poglądy i oceny w przedmiocie spraw o istotnym znaczeniu dla interesu publicznego. Ów interes wyraża się w tym, by społeczeństwo poznało informację o zarzutach naruszenia prawa lub zasad etycznych, a następnie mogło zweryfikować, czy sprawcy tych naruszeń zostali pociagnięci do stosownej odpowiedzialności ${ }^{61}$. Tak rozumiany interes publiczny może być niekiedy tak silny, że przeważa nad obowiązkiem zachowania tajemnicy służbowej ${ }^{62}$.

Trzeba ponownie podkreślić, że ujawnianie nieprawidłowości ma znaczenie dla interesu publicznego także w tych przypadkach, gdy chodzi o uchybienia popełniane $\mathrm{w}$ sektorze prywatnym ${ }^{63}$. Nietrudno bowiem wyobrazic sobie sytuację, w której przedsiębiorca nie przestrzega norm związanych z ochrona środowiska, na przykład - norm dopuszczalnych emisji toksycznych substancji. Nie jest możliwe dostrzeżenie takich nieprawidłowości przez osoby pozbawione określonej wiedzy i umiejętności, przez co grono potencjalnych sygnalistów jest właściwie ograniczone do pracowników zatrudnionych przez tego przedsiębiorcę oraz specjalistów z danej dziedziny. Jednocześnie skutki nieprawidłowości są odczuwane przez wszystkich mieszkańców, którzy sąsiaduja z jego zakładem ${ }^{64}$.

Z powyższych przyczyn wydaje się, że nie ma podstaw do różnicowania stopnia ochrony przysługujacej sygnalistom tylko z powodu charakteru ich zatrudnienia, tj. pracy na rzecz podmiotu prywatnego albo publicznego. Także przepisy dyrektywy 2019/1937 nie uzależniają ani nie modyfikują ochrony przysługującej sygnaliście tylko z tego względu, co zostało podkreślone już w samej definicji sygnalisty.

Należy zgodzić się z poglądem o doniosłym znaczeniu sygnalizacji dla rozwoju społeczeństwa demokratycznego. Ujawnianie nieprawidłowości przyczynia się do jawności (transparency) życia publicznego, co pomaga przeciwdziałać korupcji oraz innym bezprawnym czy nieetycznym zachowaniom ${ }^{65}$. Nieudzielenie ochrony sygnalistom może przy tym spowodować tak zwany efekt mrożący (chilling effect), polegajacy na niepodejmowaniu działań mających na celu ujawnienie nieprawidłowości przez osoby mające stosowne informacje z obawy przed zwolnieniem z pracy lub innego rodzaju sankcjami ${ }^{66}$.

59 Wyrok pełnego składu ETPC z 17 grudnia 1976 r. w sprawie Handyside przeciwko Wielkiej Brytanii, skarga nr 5493/72.

60 Fox (1993): 138.

61 Nowicki (2013):788-789.

62 Guja przeciwko Mołdawii: § 74; zob. także Bucur i Toma przeciwko Rumunii.

${ }^{63}$ De Maria (1995): 274.

64 Zob. na ten temat: Becker (2015): 74-76.

65 Hoedt-Rasmussen, Voorhof (2018): 3.

${ }^{66}$ Hoedt-Rasmussen, Voorhof (2018): 5. 
Z powyższych względów należy stwierdzić, że ochrona sygnalistów jest obowiązkiem pozytywnym państwa, wynikającym z konieczności ochrony wolności wypowiedzi.

Niektórzy przedstawiciele doktryny prawa pracy podnosza, że nie jest konieczne, by ochrona sygnalistów wynikała ze szczególnych przepisów, wystarczające jest bowiem obowiązująca już regulacja chroniąca pracowników przed dyskryminacja (art. $18^{3 a}$ Kodeksu pracy) ${ }^{67}$. Jednakże ETPC pozytywnie ocenia wprowadzenie szczególnych regulacji chroniących sygnalistów ${ }^{68}$.

Zagadnienie formy ochrony sygnalistów wykracza poza ramy niniejszego artykułu, jednakże wskazać należy, że w polskiej nauce prawa sformułowano postulat uchwalenia odrębnej ustawy w tym przedmiocie oraz przygotowano jej projekt ${ }^{69}$. Zasadniczymi założeniami projektu było: wprowadzenie zakazu działań odwetowych wobec sygnalisty; przeniesienie na pracodawcę ciężaru dowiedzenia, że podjęte wobec sygnalisty działania - na przykład zwolnienie z pracy - pozostawały bez związku z ujawnieniem nieprawidłowości; oraz wprowadzenie wewnętrznych procedur zgłaszania nieprawidłowości w jednostkach sektora finansów publicznych. Odnośnie do środków ochrony sygnalistów zaproponowano w szczególności: ochronę danych osobowych sygnalisty; zastosowanie sankcji nieważności ex lege wobec czynności prawnych majacych charakter działań odwetowych wobec sygnalisty oraz wyłączenie odpowiedzialności karnej i cywilnej za zgłoszenie nieprawidłowości, wszelako pod warunkiem zastosowania trybu ich zgłoszenia, przewidzianego ustawą.

Przedstawione założenia należy uznać za zasadniczo słuszne, jednakże poszczególne przepisy projektowanej ustawy wymagają bardziej pogłębionej analizy. Niezależnie jednak od formy, jaka przybierze ochrona sygnalistów, powinna ona być natychmiastowa. Sygnalista może być bowiem poddany represjom, które pozbawia go źródeł utrzymania i uniemożliwią lub poważnie utrudnią podjęcie zatrudnienia u nowego pracodawcy ${ }^{70}$. Takie ryzyko występuje szczególnie wśród wysoko wyspecjalizowanych pracowników, którzy maja ograniczone możliwości podjęcia zatrudnienia u innego pracodawcy.

Należy także podkreślić, że niezależnie od obowiązku ochrony sygnalistów wynikającego z wyżej przytoczonych powodów, na Polsce spoczywa obowiązek implementacji rozwiązań chroniących sygnalistów nałożony wskazanymi wcześniej aktami prawa międzynarodowego: Konwencją Narodów Zjednoczonych przeciwko korupcji oraz Cywilnoprawną konwencją Rady Europy o korupcji, a w szczególności - dyrektywą 2019/1937.

${ }^{67}$ Świątkowski (2015): 24-25.

${ }^{68}$ Bucur i Toma przeciwko Rumunii: $\$ 99$.

${ }^{69}$ Wojciechowska-Nowak (2012); Makowski, Waszak (2016); postulat ten popiera także Wujczyk (2014): 121. Obywatelski projekt ustawy o ochronie sygnalistów, przygotowany przez Fundację im. Stefana Batorego, Helsińską Fundację Praw Człowieka, Forum Związków Zawodowych i Instytut Spraw Publicznych dostępny na: <http://www.sygnalista.pl/projekt-ustawy/> [dostęp: 4.08.2019].

${ }^{70}$ Świątkowski (2015): 20. 


\section{PODSUMOWANIE}

Sygnalizacja pełni istotna rolę w demokratycznym społeczeństwie - pozwala na pełniejszą realizację postulatu transparentności życia publicznego oraz weryfikację funkcjonowania instytucji publicznych oraz osób pełniacych funkcje publiczne. Należy też zauważyć, iż informowanie o nieprawidłowościach stanowi realizację wolności wypowiedzi, gwarantowanej konstytucyjnie. Z uwagi na doniosłe znaczenie sygnalizacji państwo powinno zapewniać sygnaliście ochronę przed represjami - przede wszystkim w sferze stosunków pracowniczych. W przytoczonym orzecznictwie ETPC wskazano szczegółowe kryteria, jakie musi spełniać dana osoba, by można było uznać ją za sygnalistę. Spełnienie tych kryteriów oznacza, że w sytuacji konfliktu wartości: wolności wypowiedzi i ochrony praworządności z jednej strony oraz ochrony interesów i dobrego imienia pracodawcy - z drugiej, należy przyznać prymat tym pierwszym. Państwo nie może się przy tym ograniczyć do przeprowadzenia sprawiedliwego procesu w przedmiocie roszczeń sygnalisty (np. o przywrócenie do pracy). Powinno stworzyć odpowiednią procedurę ułatwiającą dokonywanie sygnalizacji bez ponoszenia jej negatywnych następstw, a w razie ich zaistnienia - przyznająca sygnaliście efektywną i szybką ochronę. W przeciwnym razie państwo naraża się na zarzut naruszenia przepisu art. 10 ust. 1 EKPC.

Artur Pietruszka

Uniwersytet im. Adama Mickiewicza w Poznaniu

artur.pietruszka@amu.edu.pl

https://orcid.org/0000-0001-5357-7944

Becker, E. (2015). Calling foul: deficiencies in approaches to environmental whistleblowers and suggested reforms. Washington and Lee Journal of Energy, Climate, and the Environment 6(1): 65-97.

Biłgorajski, A. (2013). Granice wolności wypowiedzi. Studium konstytucyjnoprawne. Warszawa.

Bychawska-Sinarska, D. (2017). Rola Europejskiego Trybunału Praw Człowieka w kształtowaniu standardów ochrony wolności słowa w Polsce. Europejski Przegląd Sądowy 2(137): 34-49.

De Maria, W. (1995). Whistleblowing. Alternative Law Journal 20(6): 270-281.

Florczak-Wątor, M. (2014). Horyzontalny wymiar praw konstytucyjnych. Kraków.

Florczak-Wątor, M. (2018). Obowiązki ochronne państwa w świetle Konstytucji RP i Europejskiej Konwencji Praw Człowieka. Kraków.

Florek, L. (2016). Ochrona pracowników jako słabszej strony stosunku prawnego, [w:] M. Boratyńska (red.), Ochrona słabszej strony stosunku prawnego. Księga jubileuszowa ofiarowana Profesorowi Adamowi Zielińskiemu: 981-992.

Fox, R.G. (1993). Protecting the whistleblower. Adelaide Law Review 15(6): 137-163.

Hoedt-Rasmussen, I., Voorhof, D. (2018). Whistleblowing for sustainable democracy. Netherlands Quarterly of Human Rights 36(3): 3-6.

Jabłoński, M. (2018). Jawność działania władz publicznych jako dobro wspólne. Ruch Prawniczy, Ekonomiczny i Socjologiczny 80(1): 39-52.

Jaśkowski, K. (2019). Komentarz do art. 45, [w:] K. Jaśkowski, E. Maniewska (red.), Kodeks pracy. Komentarz. Warszawa: 345-370.

Kamiński, I.C. (2010). Ograniczenia swobody wypowiedzi dopuszczalne w Europejskiej Konwencji Praw Człowieka. Analiza krytyczna. Warszawa.

Karaźniewicz, J. (2015). Instytucja sygnalizacji w polskim procesie karnym. Toruń 
Makowski G., Waszak, M. (2016). Ustawa o ochronie sygnalistów w Polsce - o potrzebie i perspektywach jej wprowadzenia. Warszawa. <http://www.sygnalista.pl/wp-content/uploads/2016/10/ Ustawa-o-ochronie-sygnalistow-w-Polsce_PP.pdf> [dostęp: 4.08.2019].

Nowicki, M.A. (2005). Fuentes Bobo przeciwko Hiszpanii - wyrok ETPC z dnia 29 lutego 2000 r., skarga nr 39293/98, [w:] M.A. Nowicki, Nowy Europejski Trybunał Praw Człowieka. Wybór orzeczeń 1999-2004. Kraków: 1008.

Nowicki, M.A. (2013). Komentarz do art. 10, [w:] M.A. Nowicki (red.), Wokół Konwencji Europejskiej. Komentarz do Europejskiej Konwencji Praw Człowieka. Warszawa: 761-824.

Osowski, S., Wilk, B. (2016). Jawność jako zasada demokratycznego państwa prawa. Krajowa Rada Sądownictwa 4(33): 27-34.

Ploszka, A. (2014). Ochrona demaskatorów (whistleblowers) w orzecznictwie ETPC. Europejski Przegląd Sądowy 4(103): 12-18.

Sadomski, J. (2016). Komentarz do art. 54, [w:] M. Safjan, L. Bosek (red.), Konstytucja RP. Tom 1: Komentarz do art. 1-86. Warszawa: 1278-1298.

Schubert, C. (2011). Whistle-blowing after Heinisch v. Germany. Much ado about nothing? German Yearbook of International Law 54: 753-763.

Sobczyk, A. (2015). Problem horyzontalnego działania praw jednostki w orzecznictwie sądów pracy, [w:] M. Florczak-Wątor (red.), Sądy i trybunały wobec problemu horyzontalnego działania praw jednostki. Kraków: 115-127.

Świątkowski, A.M. (2015). Sygnalizacja (whistleblowing) a prawo pracy. Przegląd Sądowy 5(116): $6-25$.

Voorhof, D. (2012). The European Convention on Human Rights: the right to freedom of expression and information restricted by duties and responsibilities in a democratic society. Human Rights 7(2): 1-40.

Wojciechowska-Nowak, A. (2012). Założenia do ustawy o ochronie osób sygnalizujących nieprawidłowości w środowisku zawodowym. Jak polski ustawodawca może czerpać z doświadczeń państw obcych? Warszawa. <http://www.sygnalista.pl/wp-content/uploads/2016/10/ AWN-Zalozenia-do-ustawy-o-ochronie-osob-sygnalizujacych-nieprawidlowosci.pdf> [dostęp: 4.08.2019].

Wojciechowska-Nowak, A. (2015). Ochrona sygnalistów, [w:] G. Makowski, C. Nowak, A. Wojciechowska-Nowak, Realizacja wybranych postanowień Konwencji Narodów Zjednoczonych przeciwko korupcji w Polsce. Warszawa. <http://www.sygnalista.pl/wp-content/ uploads/2016/10/UNCAC.pdf> [dostęp: 4.08.2019].

Wujczyk, M. (2014). Podstawy whistleblowingu w polskim prawie pracy. Przegląd Sądowy 6: 114-121.

\section{WHISTLEBLOWER PROTECTION \\ FROM THE FREEDOM OF SPEECH PERSPECTIVE}

\section{Summary}

Whistleblower protection is mainly a subject of interest for labour law. However, the jurisprudence of the European Court of Human Rights indicates the relations between whistleblower protection and freedom of speech protection. A person who discloses information about certain irregularities exercises the right to impart information, which is protected by the Polish Constitution as well as by the European Convention on Human Rights. Whistleblowing allows public institutions to be subjected to scrutiny and increases transparency in public life. Hence, a democratic society should protect a person who discloses irregularities from any sanctions that may be imposed. The aim of this paper is to establish under which circumstances a person disclosing information should enjoy protection as a whistleblower, to analyse the relations between whistleblower protection and the freedom of speech, and to consider whether the state has a positive obligation to introduce whistleblower protection.

Keywords: whistleblower; freedom of speech; positive obligations of the state 
